\title{
Extended Spectrum Beta- Lactamases: A Minireview of Clinical Relevant Groups
}

Rebecca Sullivan ${ }^{1,3 *}$, David Schaus ${ }^{1}$, Michael John ${ }^{1,2}$ and Johannes A. Delport ${ }^{1,2}$

${ }^{1}$ Division of Microbiology, Pathology and Laboratory Medicine, London Health Sciences, London, Ontario, Canada

${ }^{2}$ Schulich School of Medicine, Western University, London, Ontario, Canada

${ }^{3}$ Wilfrid Laurier University, Waterloo, Ontario, Canada

\begin{abstract}
Extended spectrum beta-lactamases are enzymes that hydrolyze the beta-lactam ring of Beta-lactam antibiotics rendering the organism resistant. ESBL prevalence is still increasing across the globe and have been implicated in hospital acquired infections and complicated urinary tract infections in Canada. TEM, SHV and CTX-M are becoming more common with CTX-M becoming more of importance as it is associated with complicated urinary tract infections. A variety of detection methods can be used including phenotypical methods, molecular methods and automated methods. Several automated instruments are commercially available to detect phenotypic resistance, recently the Clinical Laboratory Standards Institute has altered their breakpoints negating the necessity to perform confirmatory tests. Unfortunately not all of the commercial panels have the ability to detect lower breakpoints. Due to the importance of ESBL producing organisms in both hospital and community acquired infections, the associated increase in cost treating this infections and expanding spread across the globe, there is a need for further research into these enzymes.
\end{abstract}

Keywords: Extended spectrum beta-lactamases; CTX-M; TEM; SHV; CLSI Cephalosporin breakpoints; Automated detection instruments

\section{Introduction}

ESBLs are enzymes that are most commonly found in Escherichia coli and Klebsiella pneumoniae and are becoming more predominant in Enterobacteriaceae [1]. These genes are carried on plasmids and include temoneira (TEM $\beta$-lactamase), sulfhydryl variable (SHV $\beta$-lactamase) and cefotaximase (CTX-M $\beta$-lactamase) [2]. Resistance genes to other antibiotic classes are often carried on these plasmids [3].

\section{Specific Gene Variations within ESBL}

Within the ESBL family the most common genes are temoneira (blaTEM) and sulfhydryl variable (blaSHV) with increasing reports of cefotaximase (blaCTX-M) [4]. The blaSHV and the blaTEM subgroups arise from mutational changes due to point mutations in the genes resulting in subtypes. Examples include blaSHV which differs from blaSHV-1 due to a single mutation of an amino acid from glycine to serine at position 238 (G238S) [5] while the same mutation in the blaTEM gene is referred to as blaTEM-2 [6]. BlaCTX-M is becoming more prevalent, acquired on a plasmid from Kluyvera species, over 125 different subtypes of the blaCTX-M gene have been described with blaCTX-M-15 most predominant around the globe associated with clonal spread $[7,8]$. Other less familiar genes within the ESBLs include blaOXA, blaPER, blaVEB, blaCME, blaTLA, blaSFO and blaGES to name a few. BlaOXA differs from the blaOXA-10 by one amino acid mutation, either S73D or G157D. The blaPER enzyme is mainly found in Turkey and South America, the genes blaVEB, blaCME and blaTLA are closely related to the blaPER gene [5], blaSFO is closely related to class A beta-lactamases [5]. ESBLs can be categorized into four different classes: A, B, C and D. Class A denotes a serine enzyme betalactamase, class $B$ refers to metallo-beta-lactamases, class $C$ represents cephalosporinases and class D enzymes are oxacillin-hydrolyzing enzymes $[2,9]$.

\section{Prevalence of ESBL}

There have been a large number of outbreaks reported in the past decade in Africa, Asia, Europe, and North America [10,11], mostly originating in hospitals or in nursing homes [10,11]. A prevalence study was done involving 11 hospitals across Canada from 2005 to 2009, the prevalence increased in Canada from 0.12 in 2005 to 0.47 per 1000 impatient days in 2009 [10].

A study in Manitoba showed the increase of the prevalence of ESBL in E. coli and K. pneumonia from 2007 to 2011. In 2007 the prevalence of ESBL in E. coli was 3.4\%, K. pneumoniae 1.5\% and AmpC E. coli $0.7 \%$ which increased in 2011 for E. coli to $7.1 \%, K$. pneumoniae to $4.0 \%$ and AmpC E. coli to 2.9\% [11]. The prevalence of ESBL producing organisms is likely to continue to increase, as these organisms survive on surfaces and benches for prolonged periods of time and has been linked with clonal spread across the globe $[10,12]$.

\section{Detection Methods}

The detection methods include phenotypical methods and molecular methods. Examples of the former include the double disc synergy test and antibiotic gradient strips, in principle synergistic activity between the clavulanate component and another beta-lactam antibiotic is considered to be positive for an ESBL. Synergy is indicated by the enlargement of the zone around the Kirby-Bauer discs or inhibition of growth also seen on the strips [13]. The E-tests and Liofilchem strips are similar, the minimum inhibitory concentration (MIC) are read in $\mu \mathrm{g} / \mathrm{ml}$ and a positive result is defined as a two double dilution reduction between the clavulanate and non-clavulanate containing strips [12,14].

*Corresponding author: Rebecca Sullivan, Division of Microbiology, Pathology and Laboratory Medicine, London Health Sciences, London, Ontario, Canada, Tel: 1 519-685-8500; E-mail: rsulli4@uwo.ca

Received August 20, 2015; Accepted October 10, 2015; Published October 13 2015

Citation: Sullivan R, Schaus D, John M, Delport JA (2015) Extended Spectrum Beta- Lactamases: A Minireview of Clinical Relevant Groups. J Med Microb Diagn 4: 203. doi:10.4172/2161-0703.1000203

Copyright: ( 2015 Sullivan R, et al. This is an open-access article distributed under the terms of the Creative Commons Attribution License, which permits unrestricted use, distribution, and reproduction in any medium, provided the original author and source are credited. 
Although they are similar Liofilchem strips are a high-quality paper product that is easier to read, the E-test are a plastic strip which is often associated with air bubbles being trapped under the strip [14]

Molecular methods include polymerase chain reactions (PCR) and gene sequencing. These methods offer different approaches to the detection of ESBL's. Limiting factors to the implementation of these methods in routine laboratory testing includes cost, technical expertise and regional genetic variations. As these methods are dependent on a specific target sequence and local prevalence of a specific gene it is often difficult to develop an all-encompassing molecular algorithm to detect these genes. Reporting the clinical significance remains problematic as the question arises if these genes are expressed as a clinical significant entity [15]. On the other hand ESBL's may not be detected due to primer-probe target mismatch.

More recent testing involve phenotypic tests like the NDP-ESBL test and the use of Matrix-Assisted Laser Desorption/Ionization (MALDI) Time-of-Flight instruments. Both these methods relies on the betalactam ring being hydrolyzed by the ESBL enzyme. With the NDPESBL the resulting acidity is detected by the addition of a $\mathrm{pH}$ indicator, phenol red, and inhibition through the addition of tazobactam [16]. This method is faster (less than 1 hour) than PCR testing due to the ability to test from isolated colonies or clinical samples and the test has $100 \%$ specificity $[17,18]$. By analyzing the peaks on the MALDI-TOF scatter plot, hydrolysis of the beta-lactam ring can be detected $[14,19]$. The beta-lactam antibiotic gives a unique peak which disappears if the bacteria produces an ESBL enzyme (Table 1).

\section{Automated Instruments Used for Detection}

Automated instruments detect the growth in antibiotic reaction wells, comparing these to a databank of bacterial identities and corresponding susceptibility profiles. Software compares and analyzes the data to generate the final susceptibility results. Cefotaxime, ceftazidime and cefepime together with clavulanate are tested in most automated systems. The automated systems include VITEK 2 (BioMérieux, France), BD Phoenix (Becton Dickinson, United States) and MicroScan WalkAway (Siemens Healthcare Diagnostics, United States) the performance of these systems varies and differs depending on the species investigated with a much higher sensitivity (8099\%) than specificity (50-80\%) [20]. These tests are time consuming and confirmatory tests are often required [21-24]. The MicroScan WalkAway is considered to give the most comparable results to micro broth dilutions $[23,25]$.

\section{Cephalosporin Breakpoints}

All of the detection methods Double Disc Synergused determines susceptibility or resistance to $\beta$-lactam antibiotics. The revised Clinical Laboratory Standards Institute (CLSI) breakpoints for cefuroxime, cefotaxime, ceftriaxone, ceftazidime, cefpodoxime and cefepime [20] allows for detection of cephalosporin resistance negating the need to perform confirmation tests for ESBL detection. Rational for lowering the breakpoints include a greater margin of safety and better correlation between clinical achievable serum level concentrations of the cephalosporin and the MIC of the isolate [20]. Unfortunately this will in all likelihood lead

\begin{tabular}{|c|c|c|c|}
\hline Test & General Procedure & Advantages & Disadvantages \\
\hline \multicolumn{4}{|c|}{ Phenotypical methods } \\
\hline $\begin{array}{l}\text { Double Disc } \\
\text { Synergy test }\end{array}$ & $\begin{array}{c}\text { Phenotypic method. Clavunulate is used to } \\
\text { detect the presence of ESBL enzyme by having } \\
\text { a synergistic effect. }\end{array}$ & $\begin{array}{l}\text { Simple test to perform. Inexpensive compared } \\
\text { to other methods. }\end{array}$ & $\begin{array}{l}\text { Sensitivity depends on inoculum, quantity of } \\
\text { enzyme produced. Synergy or inhibition of the } \\
\text { enzyme can be overlooked by inexperienced } \\
\text { technologists. } \\
\text { Time consuming: needs at least } 18 \text { hours of } \\
\text { incubation. }\end{array}$ \\
\hline $\begin{array}{l}\text { E-tests and } \\
\text { Liofilchem gradient } \\
\text { strips }\end{array}$ & $\begin{array}{l}\text { Gradient antibiotic strip. Enhanced ratio of } \\
\text { inhibition is determined by reading the MIC. }\end{array}$ & $\begin{array}{l}\text { Phenotypic expression detected. Sensitivity is } \\
\text { high if ESBLs is actively produced. }\end{array}$ & $\begin{array}{l}\text { Does not detect the presence of genes. More } \\
\text { expensive than other phenotypic methods. The } \\
\text { E-test is plastic strips and tends to form air } \\
\text { bubbles if not applied by experienced staff. }\end{array}$ \\
\hline \multicolumn{4}{|l|}{ Molecular methods } \\
\hline $\begin{array}{l}\text { PCR and Genome } \\
\text { Sequencing }\end{array}$ & $\begin{array}{l}\text { Determine and amplify sequence of specific } \\
\text { gene primer. Detection by Real-time melting } \\
\text { curve analysis or agarose gel detection. }\end{array}$ & $\begin{array}{l}\text { Sensitive method with high efficiency; small } \\
\text { amounts of sample needed; amenable to } \\
\text { high throughput. Less time consuming than } \\
\text { phenotypic methods. }\end{array}$ & $\begin{array}{l}\text { Specificity depends on the primer selected; } \\
\text { this may result in unidentified phenotypically } \\
\text { expressed ESBL. Expensive compared to } \\
\text { phenotypic methods. Highly qualified technical } \\
\text { staff needed to perform assays. }\end{array}$ \\
\hline MALDI-ToF & Presence or absence of antibiotic is detected. & $\begin{array}{l}\text { Modified phenotypic method. Cost effective if } \\
\text { the initial equipment purchase is excluded. }\end{array}$ & $\begin{array}{l}\text { Very accurate results in experienced hands. } \\
\text { Methods are not yet accepted by accreditation } \\
\text { bodies like EUCAST or CLSI. Variable results } \\
\text { can be obtained. }\end{array}$ \\
\hline \multicolumn{4}{|c|}{ Automated instruments } \\
\hline Vitek Systems & $\begin{array}{c}\text { Use identification and susceptibility cards. } \\
\text { Wells in card is monitored for growth using light } \\
\text { attenuation measurement. }\end{array}$ & $\begin{array}{l}\text { Automated and can easily be integrated with } \\
\text { modern laboratory workflow. }\end{array}$ & $\begin{array}{l}\text { Some results may have to be verified with } \\
\text { another test (ie. Indeterminate results); isolates } \\
\text { cannot be older than } 24 \text { hours. The results are } \\
\text { determined as projection of growth, this method } \\
\text { can be less accurate than micro broth dilutions }\end{array}$ \\
\hline BD Phoenix System & $\begin{array}{l}\text { Use identification and susceptibility cards with } \\
\text { redox indicator to determine growth in wells. }\end{array}$ & $\begin{array}{l}\text { The instrument is automated and can be } \\
\text { integrated with modern laboratory workflow. } \\
\text { Results are more comparable to micro broth } \\
\text { dilution methods. }\end{array}$ & $\begin{array}{l}\text { The inoculation of the cards can be onerous. } \\
\text { The addition of an Automated preparation } \\
\text { station is required for easy workflow integration. }\end{array}$ \\
\hline $\begin{array}{l}\text { MicroScan } \\
\text { WalkAway }\end{array}$ & $\begin{array}{l}\text { Use photometric or fluorogenic reader to } \\
\text { determine growth in wells. }\end{array}$ & $\begin{array}{l}\text { Considered to be the closest instrument to } \\
\text { provide micro broth dilution comparable results. }\end{array}$ & $\begin{array}{c}\text { Longer incubation time compared to other } \\
\text { automated systems. The inoculation of the } \\
\text { wells are extremely time consuming and labour } \\
\text { intensive. }\end{array}$ \\
\hline
\end{tabular}

Table 1: Summary Table of Detection Methods of ESBLs including major advantages and disadvantages. 


\begin{tabular}{|c|c|c|c|c|c|c|c|c|c|c|c|c|}
\hline \multirow[t]{3}{*}{ Drug } & \multicolumn{6}{|c|}{ MIC } & \multicolumn{6}{|c|}{ Disk } \\
\hline & \multicolumn{3}{|c|}{ New } & \multicolumn{3}{|c|}{ Old } & \multicolumn{3}{|c|}{ New } & \multicolumn{3}{|c|}{ Old } \\
\hline & $\mathbf{S}$ & I & $\mathbf{R}$ & $\mathbf{S}$ & I & $\mathbf{R}$ & $\mathbf{S}$ & I & $\mathbf{R}$ & S & I & $\mathbf{R}$ \\
\hline Cefotaxime & $\leq 1$ & 2 & $\geq 4$ & $\leq 8$ & $16-32$ & $\geq 64$ & $\geq 26$ & 23- 25 & $\leq 22$ & $\geq 23$ & 15- 22 & $\leq 14$ \\
\hline Ceftriaxone & $\leq 1$ & 2 & $\geq 4$ & $\leq 8$ & 16- 32 & $\geq 64$ & $\geq 23$ & 20- 22 & $\leq 19$ & $\geq 21$ & $14-20$ & $\leq 13$ \\
\hline Ceftazidime & $\leq 4$ & 8 & $\geq 16$ & $\leq 8$ & 16 & $\geq 32$ & $\geq 21$ & $18-20$ & $\leq 16$ & $\geq 18$ & $15-17$ & $\leq 14$ \\
\hline Ceftizoxime & $\leq 1$ & 2 & $\geq 4$ & $\leq 8$ & $16-32$ & $\geq 64$ & $\geq 25$ & $22-24$ & $\leq 21$ & $\geq 21$ & $14-20$ & $\leq 13$ \\
\hline
\end{tabular}

†S: Susceptible; I: Intermediate; R: Resistant

Table 2: Revised and new CLSI breakpoints

to an increased use of carbapenems, associated with increased cost and potential selection of resistance to carbapenems (Table 2).

\section{Conclusion}

Although primarily in hospitals, community-acquired ESBLs are starting to become more frequent [1]. Many gene variations, and subtypes of genes, occur as a result of point mutations [26]. The blaTEM and the blaSHV subtypes are most common with the blaCTX-M becoming more frequent [1]. Automated instruments are frequently used in laboratories due to their limited labour requirement. Continued research is mandated as there is an ever expanding variation and spread of the ESBL genes.

\section{References}

1. Paterson DL, Bonomo RA (2005) Extended-spectrum $\beta$-lactamases: A clinical update. Clin Microbiol Rev 18: 657-686.

2. Shashwati N, Kiran T, Dhanvijay A (2014) Study of extended spectrum $\beta$ lactamase producing Enterobacteriaceae and antibiotic co-resistance in a tertiary care teaching hospital. J Nat Sci Biol Med 5: 30-35.

3. Ma L, Lin C, Chen J, Fung C, Chang F, et al. and the Taiwan Surveillance of Antimicrobial Resistance Project (2009) Widespread dissemination of aminoglycoside resistance genes armA and rmtB in Klebsiella pneumoniae isolates in Taiwan producing CTX-M-type extended-spectrum $\beta$-lactamases. Antimicrob Agents Chemoth 53: 104-111.

4. Sharma M, Pathak S, Srivastava $P$ (2013) Prevalence and antibiogram of extended spectrum $\beta$-lactamase (ESBL) producing gram negative bacilli and further molecular characterization of ESBL producing Escherichia coli and Klebsiella spp. J Clin Diagn Res 7: 2173-2177.

5. Bradford PA (2001) Extended-spectrum $\beta$-lactamases in the 21st century: Characterization, epidemiology, and detection of this important resistance threat. Clin Microbiol Rev 14: 933-951.

6. Kalp M, Bethel CR, Bonomo RA, Carey PR (2009) Why the extended-spectrum $\beta$-lactamases SHV-2 and SHV-5 are "Hyper susceptible" to mechanism-based inhibitors. Biochemistry 48: 9912-9920.

7. Bonnedahl J, Hernandez J, Stedt J, Waldenström J, Olsen B, et al. (2014) Extended-spectrum $\beta$-lactamases in Escherichia coli and Klebsiella pneumoniae in gulls, alaska, USA. Emerg Infect Dis 20: 897-899.

8. Cantón R, Coque TM (2006) The CTX-M $\beta$-lactamase pandemic. Curr Opin Microbiol 9: 466-475.

9. Bush K, Jacoby GA, Medeiros AA (1995) A functional classification scheme for beta-lactamases and its correlation with molecular structure. Antimicrob Agents Chemother 39: 1211-1233.

10. Lowe CF, McGeer A, Muller MP, Katz K (2012) Decreased susceptibility to non-carbapenem antimicrobials in extended-spectrum- $\beta$-lactamase-producing Escherichia coli and Klebsiella pneumoniae isolates in Toronto, Canada. Antimicrob Agents Chemother 56: 3977-3980.

11. Denisuik A, Simner P, Tailor F, Adam H, Lagacé-Wiens P, et al. (2012) Dramatic increase in the prevalence of ESBL-producing Escherichia coli (EC) in Canadian hospitals over a 5-year period.C2-103.

12. Ibrahim MK, Galal AM, Al-Turk IM, Al-Zhrany KD (2010) Antibiotic resistance in gram-negative pathogenic bacteria in hospitals' drain in Al-Madina, AlMunnawara. J Taibah Uni for Science 3: 14-22.

13. Ahmed OI, El-Hady SA, Ahmed TM, Ahmed IZ (2013) Detection of bla SHV and bla CTX-M genes in ESBL producing Klebsiella pneumoniae isolated from Egyptian patients with suspected nosocomial infections. Egypt J Med Hum Genet 14: 277-283.

14. Stürenburg E, Sobottka I, Noor D, Laufs R, Mack D (2004) Evaluation of a new cefepime-clavulanate ESBL E-test to detect extended-spectrum $\beta$-lactamases in an Enterobacteriaceae strain collection. J Antimicrob Chemother 54: 134-138.

15. Mardis ER (2008) Next-generation DNA sequencing methods. Ann Rev Genomics Hum Genet 9: 387-402.

16. Tharavichitkul P, Kaewmalakul J, Khanthawa B (2012) The rapid-simpleESBL test in Escherichia coli and Klebsiella pneumoniae. Int J Infect Dis 16, Supplement 1: e405.

17. Nordmann P, Poirel L, Dortet L (2014) Rapid detection of ESBL-producing Enterobacteriaceae from blood cultures: A prospective study. Internat J Infect Dis. 21, Supplement 1: 365-366.

18. Nordmann P, Dortet L, Poirel L (2012) Rapid detection of extended-spectrumß-lactamase-producing Enterobacteriaceae. J Clin Microbiol 50: 3016-3022.

19. Sparbier K, Schubert S, Weller U, Boogen C, Kostrzewa M (2012) Matrixassisted laser desorption lonization-Time of flight mass spectrometry-based functional assay for rapid detection of resistance against $\beta$-lactam antibiotics. J Clin Microbiol 50: 927-937.

20. Kahlmeter G (2008) Breakpoints for intravenously used cephalosporins in Enterobacteriaceae - EUCAST and CLSI breakpoints. Clin Microbiol Infect. 14 Supplement 1: 169-174.

21. Rhoads S, Marinelli L, Imperatrice CA, Nachamkin I (1995) Comparison of MicroScan WalkAway system and Vitek system for identification of gramnegative bacteria. J Clin Microbiol 33: 3044-3046.

22. Stürenburg E, Sobottka I, Feucht H, Mack D, Laufs R (2003) Comparison of BD Phoenix and VITEK2 automated antimicrobial susceptibility test systems fo extended-spectrum beta-lactamase detection in Escherichia coli and Klebsiella species clinical isolates. Diagn Microbiol Infect Dis. 45: 29-34

23. Snyder JW, Munier GK, Johnson CL (2008) Direct comparison of the BD phoenix system with the MicroScan WalkAway system for identification and antimicrobial susceptibility testing of Enterobacteriaceae and nonfermentative gram-negative organisms. J Clin Microbiol 46: 2327-2333.

24. Leverstein-van Hall MA, Fluit AC, Paauw A, Box ATA, Brisse S, et al. (2002) Evaluation of the E-test ESBL and the BD phoenix, VITEK 1, and VITEK 2 automated instruments for detection of extended-spectrum beta-lactamases in multiresistant Escherichia coli and Klebsiella spp. J Clin Microbiol 40: 37033711.

25. Drieux L, Brossier F, Sougakoff W, Jarlier V (2008) Phenotypic detection of extended-spectrum beta-lactamase production in Enterobacteriaceae: review and bench guide. Clin Microbiol Infect 14, Supplement 1: 90-103.

26. (2015) Clinical and Laboratory Standards Institute. Performance standards for antimicrobial susceptibility testing; Twenty-fifth informational supplement M100-S25. Clinical and Laboratory Standards Institute, Wayne, PA. 